\title{
Bioactive compounds in the algae of Kappaphycus alvarezii from Belang waters, Southeast Minahasa Regency
}

\author{
Indonesian title: \\ Senyawa bioaktif pada alga Kappaphycus alvarezii dari perairan Belang, \\ Kabupaten Minahasa Tenggara
}

\author{
Dias Asthisa $^{1 *}$, Desy M.H Mantiri², Deiske A. Sumilat ${ }^{1}$, Rizal M. Rompas ${ }^{2}$, Annita Ch. Sinjal2 \\ Rose O.S.E Mantiri ${ }^{2}$

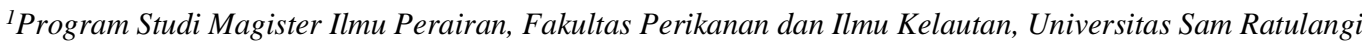 \\ Jl. Kampus Unsrat Bahu, Manado 95115 Sulawesi Utara, Indonesia \\ ${ }^{2}$ Fakultas Perikanan dan Ilmu Kelautan, Universitas Sam Ratulangi, Jl. Kampus Unsrat Bahu, \\ Manado 95115, Sulawesi Utara, Indonesia \\ *Corresponding author: diasastisa97@gmail.com
}

Received: 21 July 2021 - Revised: 3 September 2021 - Accepted: 12 October 2021

\begin{abstract}
Algae Kappaphycus alvarezii is one of the leading commodities from fisheries and marine sectors in Indonesia. This algae species has many benefits in the fields of marine biology, chemistry, pharmacy, and pharmacology, as well as an excellent nutritional content for health. It is cultivated in the coastal waters of Minahasan Peninsula, especially in Buku Village, Belang District, Southeast Minahasa Regency. This study was carried out to analyze bioactive compound in the algae. Samples of 2-weeks old were taken directly from the cultivation area. Screening test was done qualitatively while an advanced test was done using LC-HRMS method. The results showed 4 bioactive compounds detected in the sample, they are alkaloids, tannins/phenolics, saponins, and flavonoids. From the advanced test, it was found 10 major compounds in the sample, i.e. (2-ethylhexyl) phthalate, phthalic acid, D-(+)-proline, maraniol, stigmatellin Y, Pentyl isopentyl phthalate, methyl thiofentanyl, phenylethanolamine, acetyl hexamethyl tetralin, and fucoxanthin.
\end{abstract}

Keywords: algae; Kappaphycus alvarezi; bioactive compound; LC-HRMS; Minahasa

\section{PENDAHULUAN}

Sumber daya hayati laut perlu dimanfaatkan secara optimal. Salah satu sumber daya hayati laut yang bermanfaat ialah rumput laut (alga), khususnya jenis Kappaphycus alvarezii. Alga K. alvarezii adalah salah satu komoditas unggulan di bidang perikanan dan kelautan Indonesia, karena alga jenis ini menghasilkan karagenan yang bernilai ekonomis tinggi (Sarira and Pong-Masak, 2019).

Menurut Bold and Wynne (1985), alga diklasifikasikan dalam tiga kelas besar, yaitu Chlorophyceae (alga hijau), Phaeophyceae (alga cokelat), dan Rhodophyceae (alga merah). Beberapa jenis alga merupakan sumber potensial pangan fung- sional yang dapat dimanfaatkan untuk kesehatan, karena mengandung senyawa kimia yang mempunyai aktivitas biologis (zat bioaktif). Senyawa aktif biologis itu merupakan metabolit sekunder, yang meliputi alkaloid, flavonoid, terpenoid, tannin, dan saponin. Menurut Saleh et al. (2019), terdapat sekitar 2.500 jenis senyawa bioaktif dari laut yang telah berhasil diisolasi dan diidentifikasi, 93\% di antaranya diperoleh dari alga.

Dalam upaya memanfaatkan sumber daya hayati secara optimal, khususnya alga dari perairan Sulawesi Utara, maka dilakukan penelitian yang bertujuan untuk menganalisis senyawa bioaktif yang terkandung dalam alga $K$. alvarezii. 


\section{MATERIAL DAN METODE}

Penelitian ini dilaksanakan pada bulan Juli 2020 sampai dengan Maret 2021. Pengambilan sampel alga $K$. alvarezii dilakukan di perairan pesisir Minahasa Tenggara, Desa Buku Kecamatan Belang, Provinsi Sulawesi Utara (Gambar 1).

Sampel berumur 2 minggu, diambil secara langsung dari lahan budidaya rumput laut. Identifikasi morfologi sampel alga $K$. alvarezii dilakukan di Laboratorium Biomolekuler dan Farmasitika Laut, Fakultas Perikanan dan Ilmu Kelautan, Universitas Sam Ratulangi (Unsrat) Manado, menggunakan panduan Trono (1997). Untuk mengetahui senyawa bioaktif di dalam sampel, 2 macam analisis laboratorium dilakukan, yaitu skrining fitokimia, yang dilakukan di Lab. FMIPA Unsrat, dan pengujian lanjut, yang dilakukan di Lab. Sentral Ilmu Hayati, Universitas Brawijaya, Malang, menggunakan Liquid ChromatographyHigh Resolution Mass Spectrometry (LC-HRMS). Skrining fitokimia dilakukan dengan maserasi (maceration), yang merupakan metode umum untuk mengekstraksi tumbuh-tumbuhan (Ncube et al., 2008). Dalam skrining tersebut, senyawa bioaktif yang terkandung pada sampel diuji secara kualitatif berdasarkan perubahan warna atau endapan yang terbentuk sebagai respon terhadap reagen yang diberikan.

\section{HASIL DAN PEMBAHASAN}

\section{Senyawa Bioaktif Alga K. alvarezii}

Hasil skrining senyawa bioaktif pada alga $K$. alvarezii, yang terdeteksi adalah senyawa alkaloid, tanin/polifenol, saponin, dan flavonoid (Tabel 1). Berikut ini adalah karakteristik dan manfaat masingmasing bioaktif tersebut:

\section{- Senyawa alkaloid}

Alkaloid adalah senyawa metabolit sekunder terbanyak yang memiliki atom nitrogen, yang ditemukan dalam jaringan tumbuhan dan hewan. Sebagian besar senyawa alkaloid bersumber dari tumbuh-tumbuhan. Alkaloid pada tumbuhan berfungsi sebagai racun yang dapat melindunginya dari herbivora dan serangga. Alkaloid selama bertahun-tahun telah menarik perhatian terutama karena pengaruh fisiologisnya dalam bidang farmasi (Ningrum et al., 2016). Alkaloid berkhasiat sebagai anti diare, anti diabetes, anti mikroba dan anti

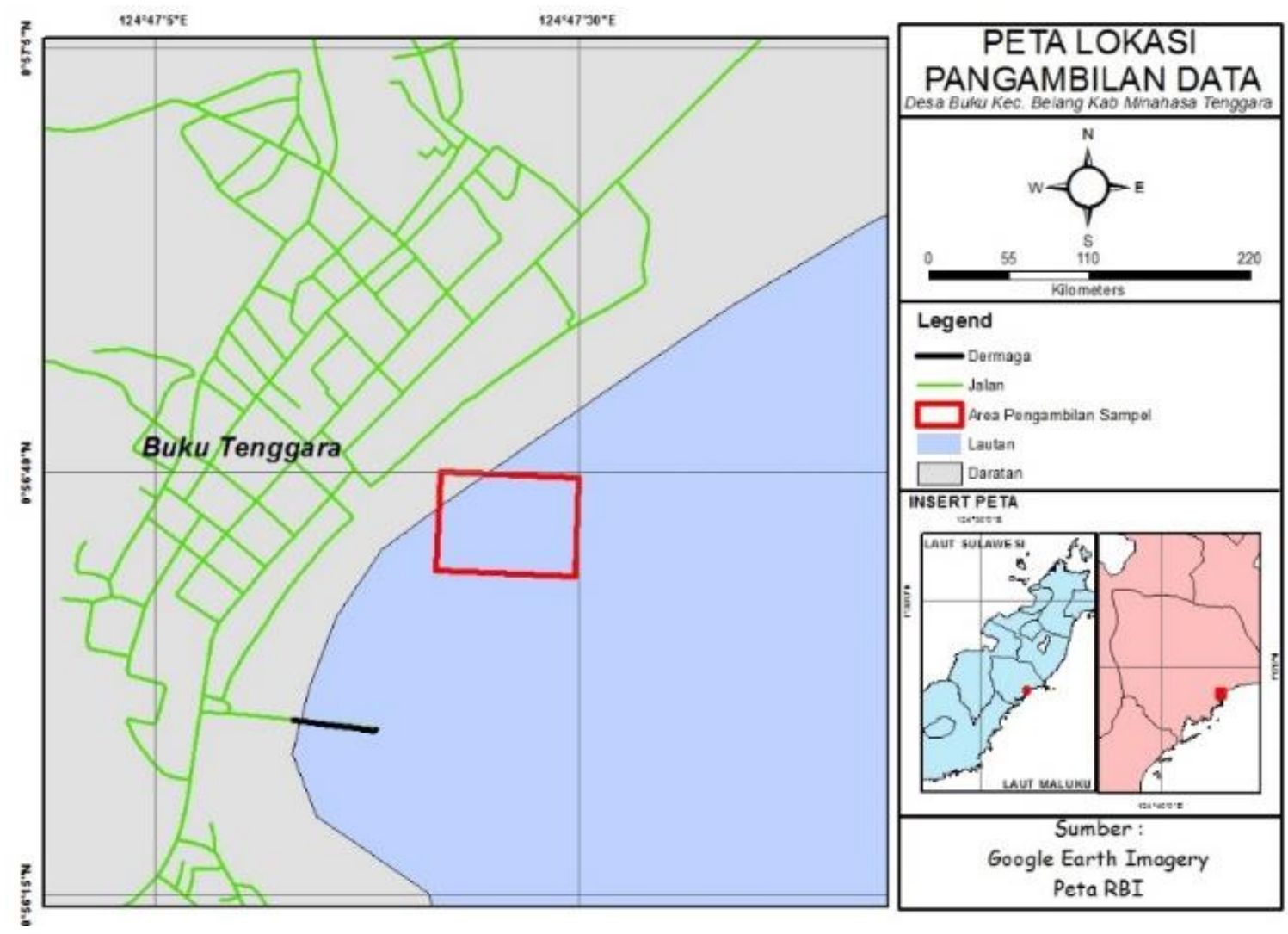

Gambar 1. Peta lokasi pengambilan data di Desa Buku, Kecamatan Belang, Kabupaten Minahasa Tenggara 
Asthisa et al.: Bioactive compounds in the algae of Kappaphycus alvarezii from Belang waters ...

Tabel 1. Hasil Uji skrining fitokimia pada sampel alga K. Alvarezii

(-: absence; +: poor presence; +++: luxuriant presence)

\begin{tabular}{lcl}
\hline Golongan senyawa & Hasil & Perubahan warna \\
\hline Alkaloid (Dragendorf, Wagner, Meyer) & ++ & Dragendorf: jingga \\
& & Wagner: cokelat \\
& & Meyer: endapan putih \\
Flavonoid & + & merah \\
Tanin & + & hijau \\
Saponin & + & gelembung/buih \\
Steroid & - & tidak ada perubahan warna \\
Triterpenoid & + & ada perubahan warna merah \\
\hline
\end{tabular}

malaria. Alkaloid meningkatkan dilatasi pembuluh darah pada alat kelamin pria. Selain itu juga dapat menginduksi vasodilatasi sehingga menimbulkan ereksi (Fahruni et al., 2018).

\section{- Senyawa tanin/polifenol}

Tanin memiliki peranan biologis yang kompleks mulai dari pengendap protein hingga pengkhelat logam. Tanin juga dapat berfungsi sebagai antioksidan biologis (Malangngi et al., 2012). Manfaat tanin antara lain dipakai dalam industri farmasi, industri pengolahan kulit, industri minuman dan industri pembuatan tinta (Dhora, 2017). Tanin mempunyai manfaat sebagai di antaranya antikarsinogen, memiliki efek anthelmitic (Hana et al., 2018).

\section{- Senyawa Saponin}

Manfaat dari saponin adalah sebagai spermisida (obat kontrasepsi laki-laki), anti peradangan, dan aktivitas sitotoksik (Purnobasuki, 2004). Saponin memiliki berbagai macam sifat biologis seperti kemampuan hemolitik, antimolluska, aktivitas antibakterial, efek hipokolesterolemia, aktivitas antivirus (Yanuartono et al., 2017) dan anti protozoa, serta aktivitas sitotoksik atau anti kanker (Agarwal, 2016). Selain itu, senyawa saponin berkhasiat sebagai antifungi, antibakteri, menghambat pertumbuhan sel tumor dan memiliki kemampuan menurunkan kolesterol dalam darah. Saponin memiliki kemampuan menghambat pertumbuhan bakteri maupun fungi (Yanuartono et al., 2017).

\section{- Senyawa Flavonoid}

Flavonoid ditemukan pada tanaman, yang berkontribusi memproduksi pigmen berwarna kuning, merah, jingga, biru, dan warna ungu dari buah, bunga, dan daun. Flavonoid merupakan salah satu senyawa alami yang dapat mengobati berbagai penyakit seperti anti oksidan, bakteri patogen, radang, disfungsi kardio-vaskular, dan dalam mencegah terjadinya luka akibat radikal bebas (Arifin \&
Ibrahim 2018). Flavonoid adalah metabolit sekunder dari polifenol, memiliki berbagai efek bioaktif termasuk anti virus, anti inflamasi (Wang et al., 2016). Antioksidan, anti mikroba, anti HIV, anti tumor, anti fungal, analgesik, anti diare, anti hepatotoksik, anti radang, immuno stimulant, anti hiperglikemik, sebagai vasolidator (Pratiwi, 2016). Sebagai obat infeksi pada luka, anti jamur, anti bakteri, sitotoksik, anti hipertensi anti kanker, anti alergi (Dewi \& Wahyuni, 2018).

\section{Senyawa Utama pada Alga K. alvarezii}

Hasil pengujian lanjut menggunakan LCHRMS, ditemukan 10 senyawa utama yang terkandung di dalam alga $K$. alvarezii, yaitu senyawa (2ethylhexyl) phthalate, phthalic acid, D-(+)-proline, maraniol/methyl coumarin, stigmatellin $\mathrm{Y}$, pentyl isopentyl phthalate, methyl thiofentanyl, phenylethanolamine, acetyl hexamethyl tetralin/ tonalide, dan fucoxanthin (Tabel 2). Berikut ini adalah karakteristik dari senyawa tersebut:

\section{- (2-ethylhexyl) phthalate}

Senyawa (2-ethylhexyl) phthalate adalah senyawa organik dengan rumus $\mathrm{C}_{26} \mathrm{H}_{45} \mathrm{NO}_{4}$. Derivat phthalate, seperti di-2-ethylhexyl phthalate (DEHP), banyak digunakan pada plastik (Saad, 2014).

\section{- Phthalic acid}

Phthalic acid adalah senyawa dikarbosilat aromatik. Senyawa ini tidak berwarna, berbentuk kristal padat yang larut dalam alkohol dan air, mempunyai gugus hidroksil yang bersifat polar. Senyawa ini merupakan senyawa yang memiliki 6 gugus cincin benzen yang bersifat aromatis (Khotimah et al., 2013).

- D-(+)-proline

Proline merupakan senyawa metabolit osmotik yang disintesis dan diakumulasi pada berbagai jaringan tanaman terutama pada daun apabila tanaman menghadapi tekanan kekeringan 
Aquatic Science \& Management, Vol. 9, No. 2 (October 2021)

Tabel 2. Sepuluh puncak senyawa pada alga $K$. alvarezii menggunakan LC-HRMS

\begin{tabular}{lll}
\hline Senyawa & Formula & Puncak senyawa \\
\hline (2-ethylhexyl) phthalate & $\mathrm{C} 26 \mathrm{H} 45 \mathrm{NO} 4$ & 97,4 \\
Phthalic acid & $\mathrm{C} 8 \mathrm{H} 4 \mathrm{O} 3$ & 96,7 \\
D-(+)-Proline & $\mathrm{C} 5 \mathrm{H} 9 \mathrm{NO} 2$ & 95,4 \\
Maraniol & $\mathrm{C} 12 \mathrm{H} 12 \mathrm{O} 3$ & 94,7 \\
Stigmatellin Y & $\mathrm{C} 29 \mathrm{H} 40 \mathrm{O} 6$ & 94,5 \\
Pentyl isopentyl phthalate & $\mathrm{C} 7 \mathrm{H} 4 \mathrm{O} 2$ & 94,2 \\
Methyl thiofentanyl & $\mathrm{C} 21 \mathrm{H} 28 \mathrm{~N} 2 \mathrm{OS}$ & 94 \\
Phenylethanolamine & $\mathrm{C} 8 \mathrm{H} 9 \mathrm{~N}$ & 91,3 \\
Acetyl hexamethyl tetralin & $\mathrm{C} 18 \mathrm{H} 26 \mathrm{O}$ & 88,9 \\
Fucoxanthin & $\mathrm{C} 42 \mathrm{H} 58 \mathrm{O} 6$ & 81,5 \\
\hline
\end{tabular}

(Hamim et al., 2008). Senyawa ini merupakan senyawa osmotikum yang berperan dalam peningkatan daya tahan terhadap cekaman air dari lingkungannya sehingga banyak diakumulasikan pada kondisi ketersediaan air rendah. Fenomena tersebut dideskripsikan sebagai osmoregulasi dan penyesuaian osmosis.

\section{- Maraniol/Methyl Coumarin}

Senyawa Coumarin biasanya terdapat dalam senyawa polar maupun yang bersifat non polar (Harborne, 1987). Senyawa ini memiliki berbagai macam kegunaan, seperti fiksatif dalam makanan dan kosmetik, obat-obatan, insektisida, rodentisida dan untuk menutupi bau yang tidak menyenangkan dalam produk industri, seperti tinta cetak, cat, dan karet sintetis (Al-Bayati et al., 2010).

\section{- Stigmatellin Y}

Stigmatellin Y memiliki potensi penghambatan biofilm dan dapat digunakan untuk terapi virulen anti Pseudomonas (Boopathi et al., 2017). Pseudomonas umum dirumuskan sebagai gramnegatif, berbentuk batang bakteri yang dapat menyebabkan penyakit pada tanaman dan hewan, termasuk manusia (Diggle and Whitley 2020).

\section{- Pentyl isopentyl phthalate}

Senyawa ini digunakan pada aplikasi lain, seperti di farmasi, cat, lem, bahan pembersih dan bangunan (Tsochatzis et al., 2017). Struktur kimiawi senyawa ini terdiri dari satu cincin benzen yang dihubungkan dengan dua gugus fungsi ester pada posisi 1 dan 2 pada cincin (Katsikantami et al., 2016).

- Methyl thiofentanyl

Thiofentanyl adalah analgesik opioid yang merupakan analog dari fentanyl. Analgesik yang merupakan obat yang digunakan untuk mengurangi atau menghilangkan rasa sakit atau obat-obatan penghilang nyeri tanpa menghilangkan kesadaran. Obat ini digunakan untuk membantu meredakan sakit (Mita and Husni 2017).

- Phenylethanolamine (PEA)

Phenylethanolamine (PEA) telah digunakan secara ilegal dalam beberapa tahun terakhir pada hewan ternak yang ada di China. Senyawa ini bisa memberikan dampak secara tidak langsung jika manusia memakan produk daging dari hewan yang telah terakumulasi PEA. Manusia yang memakan daging tersebut dapat mengalami pusing, detak jantung cepat, tremor otot, palpitasi, gejala dispnea, atau bahkan kematian pada kasus yang parah (Bai et al., 2012).

- Acetyl hexamethyl tetralin/ Tonalide

Tonalide (AHTN) mewakili sekitar 95\% dari total bahan wewangian di industri parfum dan yang paling banyak terdeteksi di lingkungan dan jaringan biologis (Peck et al., 2004).

\section{- Fucoxanthin}

Fucoxanthin dari alga memiliki potensi yang besar untuk dikembangkan sebagai bahan nutraseutikal (Peng et al., 2011). Senyawa ini memiliki bioaktivitas yang sangat baik sebagai penangkal radikal bebas (D'orazio et al., 2012). Selain itu, senyawa ini sangat berpotensi dijadikan zat aktif untuk sediaan obat dan kosmetik dan anti peradangan (Jaswir et al., 2011), berperan dalam menghambat pertumbuhan sel kanker pada hati (Noviendri et al., 1996). 
Asthisa et al.: Bioactive compounds in the algae of Kappaphycus alvarezii from Belang waters ...

\section{KESIMPULAN}

Di dalam alga $K$. alvarezii, terdeteksi 4 senyawa bioaktif, yaitu alkaloid, tanin/polifenol, saponin, dan flavonoid. Selain itu, ditemukan juga 10 senyawa utama, yaitu (2-ethylhexyl) phthalate, phthalic acid, D-(+)-proline, maraniol/methyl coumarin, stigmatellin Y, pentyl isopentyl phthalate, methyl thiofentanyl, phenylethanolamine, acetyl hexamethyl tetralin/ tonalide, dan fucoxanthin.

Ucapan terima kasih. Disampaikan terima kasih kepada semua pihak yang telah membantu dalam pelaksanaan penelitian dan penulisan naskah hasil penelitian untuk publikasi dalam jurnal ilmiah. "Kami menyatakan bahwa tidak ada konflik kepentingan dengan organisasi manapun mengenai bahan yang didiskusikan dalam naskah ini”.

\section{REFERENSI}

AGARWAL, A. (2016) Duality of anti-nutritional factors in pulses. Journal of Nutritional Disorders \& Therapy, 6 (1), pp. 1-2.

AL-BAYATI, R.I., AL-AMIERY, A.A.H. and ALMAJEDY, Y.K. (2010) Design, synthesis and bioassay of novel coumarins. African Journal of Pure and Applied Chemistry, 4 (6), pp. 74-86.

ARIFIN, B. and IBRAHIM, S. (2018) Struktur, bioaktivitas dan antioksidan flavonoid. Jurnal Zarah, 6 (1), pp. 21-29.

BAI, Y., LIU, Z., BI, Y., WANG, X., JIN, Y., SUN, L., WANG, H., ZHANG, C. and XU, S. (2012) Preparation of polyclonal antibodies, and development of a direct competitive enzimelinked immunosorbent assay to detect residues of phenylthanolamine A in urine sampels. Journal of Agricultural and Food Chemistry, 60 (46), pp. 11618-11624.

BOLD, H.C. and WYNNE, M.J. (1985) Introduction to the Algae. Pretice, Inc. England.

BOOPATHI, S., VASHISTH, R., MANOHARAN, P., KANDASAMY, R. and SIVAKUMAR, N. (2017) Stigmatellin Y-an anti-biofilm compound from Bacillus subtilis BR4 possibly interferes in PQS-PqsR mediated quorum sensing system in Pseudomonas aeruginosa. Bioorganic \& Medicinal Chemistry Letters, 27 (10), pp. 21132118.

D'ORAZIO, N., GEMELLO, E., GAMMONE, M.A., de GIROLAMO, M., FICONERI, C. and RICCIONI, G. (2012). Fucozantin: a treasure from the sea. Marine Drugs, 10 (3), pp. 604-616.
DEWI, S.T.R. and WAHYUNI, S. (2018) Uji efek anti inflamasi rebusan daun jamblang (Syzygium cumini) pada mencit (Mus musculus). Media Farmasi, 14 (1), pp. 53- 59.

DHORA, A. (2017) Ekstraksi tanin pada daun ketapang (Terminalia catappa L.) dengan variasi pelarut, konsentrasi pelarut dan lama waktu ekstraksi. Jurnal Agroindustri Halal, 3 (2), pp. 142-151.

DIGGLE, S.P. and Whiteley, M. (2020) Microbe profile: Pseudomonas aeruginosa: opportunistic pathogen and lab rat. Microbiology (Reading), 166 (1), pp. 30-33.

FAHRUNI, F., HANDAYANI, R. and NOVARYATIIN, S. (2018) Potensi tumbuhan kelakai (Stenochlaena palustris (Burm.F.) Bedd.) asal Kalimantan Tengah sebagai afrodisiaka. Jurnal Surya Medika, 3 (2), 144-153.

HAMIM, H., ASHRI, K., MIFTAHUDIN and TRIADIATI (2008) Analisi status air, prolin dan aktivitas enzim antioksidan beberapa kedelai toleran dan peka kekeringan serta kedelai liar. Agrivita, 30 (3), 201-210.

HANA, C.M., SUNYOTO and ROHMAT, N. (2018) Penetapan kadar tanin dari kulit buah pisang raja masak (Musa Paradisiaca L.) secara spektrofotometri UV-Vis. Motorik, 13 (26), pp. 28-39.

HARBORNE, J.B. (1987) Metode Fitokimia: Penuntun cara modern menganalisis tumbuhan. Terbitan Kedua. Bandung: ITB Bandung.

JASWIR, I., NOVIENDI, D., SALLEH, H.M., TAHER, M. and MIYASHITA, K. (2011) Isolation of fucoxanthin and fatty acids analysis of Padina australis and cytotoxic effect of fucoxanthin on human lung cancer (H1299) cell lines. African Journal of Biotechnology, 10 (81), pp. 18855-18862.

KATSIKANTAMI, I., SIFAKIS, S., TZATZARAKIS, M.N., VAKONAKI, E., KALANTZI, O-I., TSATSAKIS, A.M. and RIZOS, A.K. (2016) A global assessment of phthalates burden and related links to health effects. Environment International, 97, pp. 212-236.

KHOTIMAH, K.K., Darius, D.D. and SASMITO, B.B. (2013) Uji aktivitas senyawa aktif alga cokelat (Sargassum fillipendulla) sebagai antioksidan pada minyak ikan lemuru (Sardinella longiceps). THPi Student Journal, I (1), pp. 1020.

MALANGNGI, L., SANGI, M. and PAENDONG, J. 2012. Penentuan kandungan tanin dan uji aktivitas antioksidan ekstrak biji buah alpukat (Persea americana Mill.). Jurnal MIPA Unsrat Online, 1 (1), pp. 5-10. 
MITA, S.R. and HUSNI, P. (2017). Pemberian pemahaman mengenai penggunaan obat analgesik secara rasional pada masyrakat di Arjasari Kabupaten Bandung. Dharmakarya: Jurnal Aplikasi Ipteks untuk Masyarakat, 6 (3), pp. 193-195.

NCUBE, N.S., AFOLAYAN, A.J. and OKOH, A.I. (2008) Assesment technique of antimicrobial properties of natural compound of plant origin: current methods and future trends. African Journal of Biotechnology, 7 (12), pp. 1797-1806

NINGRUM, R., ELLY, P. and SUKARSONO (2016) Identifikasi senyawa alkaloid dari batang karamunting (Rhodomyrtus tomentosa) sebagai bahan ajar biologi untuk SMA kelas X. Jurnal Pendidikan Biologi Indonesia, 2 (3), pp. 231-236.

NOVIENDRI, D., JASWIR, I., SALLEH, H.M., TAHER, M., MIYASHITA, K. and RAMLI, N. (2011). Fucoxanthin extraction and fatty acid analysis of Sargassum binderi and S. duplicatum. Journal of Medicinal Plants Research, 5 (11), pp. 2405-2412.

PECK, A.M. and HORNBUCKLE, K.V. (2004) Synthetic musk fragrances in Lake Michigan. Environmental Science and Technology, 38 (2), pp. 367-372.

PENG J., YUAN, J-P., WU, C-F. and WANG, J-H. (2011) Fucoxanthin, a marine carotenoid present in brown seaweeds and diatoms: metabolism and bioactivities relevant to human health. Marine Drugs, 9 (10), pp. 1806-1828.

PRATIWI, R.D. (2016) Uji Kualitatif fitokimia daun Ruta angustifolia. Faktor Exacta, 9 (3), pp. 200206.

PURNOBASUKI, H. (2004) Potensi mangrove sebagai tanaman obat. Biota, IX (2), pp. 125-126.
SAAD, M.M-E. (2014) The most recent hadard of phthalate that threaten food safety and human health. International Journals of Medical Science and Clinical Inventions, 1 (10), pp. 527-535.

SALEH, A.A.G.A., ASNANI, A. and SUWARJOYOWIRAYATNO, S. (2019) Uji fitokimia dan aktivitas antioksidan cendol yang diformulasi dari rumput laut (Kappaphycus alvarezii) dan tepung sagu (Metroxylon sagus Rottb.). Jurnal Fish Protech, 2 (1), pp. 38-45.

SARIRA, N.H. and PONG-MASAK, P.R. (2019) Seaweed selection to supply superior seeds for cultivation. Jurnal Perikanan Universitas Gadjah Mada, 20 (2), pp. 79-85.

TRONO, G.C. (1997) Field Guide and Atlas of the Seaweed. National Book Store. Philippines: Publisher Metro Manila.

TSOCHATZIS, E.D., TZIMOU-TSITOURIDOU, R. and GIKA, H.G. (2017) Analytical methodologies for the assessment of phthalate exposure in humans. Critical Reviews in Analytical Chemistry, 47 (4), pp. 279-297.

WANG, Q., JIN, J., DAI, N., HAN, N., HAN, J. and BAO, B. 2016. Anti-inflammatory effects, nuclear magnetic resonance identification, and high-performance liquid chromatography isolation of the total flavonoids from Artemisia frigida. Journal of Food and Drug Analysis, 24 (2), pp. 385-391.

YANUARTONO, PURNAMANINGSIH, H., NURURROZI, A. and INDARJULIANTO, S. (2017) Saponin: dampak terhadap ternak. Jurnal Peternakan Sriwijaya, 6 (2), pp. 79-90. 